\title{
ВЛИЯНИЕ МИГРАЦИОННЫХ ПРОЦЕССОВ НА ФОРМИРОВАНИЕ НОВОЙ МОДЕЛИ ЭКОНОМИЧЕСКОГО РАЗВИТИЯ
}

\author{
(c) 2020 Наумов Александр Сергеевич \\ кандидат экономических наук, старший научный сотрудник \\ Институт экономики РАН, Россия, Москва \\ E-mail: as.naumov@mail.ru
}

Рассматриваются социально-экономические проблемы и пути их решения в свете структурных преобразований российской экономики: рациональное использование ресурсной базы, инвестиции в экономические «точки роста», создание социальной инфраструктуры развивающихся агломераций, плюсы и минусы современной российской урбанизации с точки зрения зарубежного опыта, роль государства в экономических преобразованиях, роль науки в изменении политического и экономического положения, пересмотре существующих стратегий развития и структур управления экономикой (оценка политической, экономической и социо-культурной ситуации в России).

Ключевые слова: урбанизация, миграционные процессы, малые города, Хабитат, ООН, социальноэкономические условия, ресурсная база, саморазрушающаяся экономика, неоэкономика, пространство, территория.

Пространственно-миграционные процессы, происходившие на территории России в период ее формирования и происходящие по настоящее время, являются одними из основных факторов, влияющих на принципы формирования национальной идеи в новых экономических условиях. Образование новых государств всегда проходит через формирование определенной идеологии или встраивание в нее изначальной специфики (ментальности). В России, как утверждал Л. Никифоров, «преградой этому стала принудительная капитализация страны, не считающаяся с ее экономическими, социальными, национальными особенностями и социально-психологическими чертами народа» [1, с. 125]. По его мнению - объединение, общность, целостности, при разнообразии условий, должна стать национальной идеей народонаселения страны, что полностью, по его мнению, соответствует его менталитету, выработанному веками. Для подтверждения этого тезиса необходимо обратиться к истории России. Начать надо с высказывания политэконома позапрошлого века С.Н.Булгакова, который заявлял следующее: «Обновиться же Россия не может, не обновив (вместе с многим другим) прежде всего и свою интеллигенцию. И говорить об этом громко и открыто есть долг убеждения и патриотизма» [2, с. 6]. О чем идет речь? Это славянофилы и западники. Эти течения русской мысли не надо рассматривать как противоположности, разделяющие общество. Очевидно то, что и те и другие по своему правы. Недопонимание этого приводит к тому, что экономика России становится похожа на «тянитолкая» из сказки К. Чуковского, мешая ей развиваться. Подкрепим наши размышления высказыванием российского исследователя А.К Топоркова из статьи «Идея славянского возрождения», написанной в 1915 г. (под псевдонимом А.Немов): «Западничество в настоящее время возможно не как общее миросозерцание, а лишь в узком и техническом смысле этого слова. И теперь и позже русские общественные деятели и техники будут посещать западные города, фабрики и заводы, знакомиться с устройством кооперативных товариществ и канализации и т.д., т.е. русские еще долго будут пользоваться опытами более зрелой и более мощной культуры Запада, но все эти вопросы частные и специальные, они не могут заменить более общих, более отвлеченных, быть может, но тем не менее гораздо более нужных, чем последние,- вопросов о целях и идеалах. Если Возрождение не наступит, то тщетными будут все победы, не сбывшимися останутся наши надежды, только возрождение закрепит за нами приобретения нашего оружия и даст новый смысл нашему существованию» [3, с.23-24]. Становится очевидным, что современные утверждения об особой русской цивилизации имеют под собой достаточные основания, как имеются под собой те же основания у японцев, китайцев, немцев и т.д. Какое же влияние 
оказывал в прошлом и оказывает в настоящем этот факт на жизнь российского народа? Неравномерность его расселения, имеющая, по словам Г. Гачева, «горизонтальную направленность» [4, с. $17,115]$, является главным тормозом экономического и социального развития. Не спасают здесь ни современный транспорт, ни развитие высоких технологий. Отсутствует общественное разделение труда и, как результат,- промышленный застой и деградация территорий. В странах Западной Европы главенствовала линия вертикального развития в виду сравнительно малых территорий.

Стоит, например, припомнить выражение - «до Бога высоко, а до царя далеко», чтобы убедиться в справедливости высказанного положения, приведем размышления академика М.К.Любавского в книге «Историческая география России в связи с колонизацией», представляющей собой уникальное издание: «Конечно, нельзя все в данном случае относить на счет непомерной величины территории и разбросанности населения. Но, во всяком случае, эта разбросанность была и есть одной из главных задержек гражданского прогресса в нашей стране» [5, с. 11]. Разъединение территорией, так можно обозначить смысл его обширного труда, что, кстати, объясняет происхождение российского государственного устройства как централизации власти и попечительства. «Чрезвычайно важно уяснить, как создавалось такое положение вещей, что заставило русский народ так распространиться, так разбрестись розно по необъятной территории. Ведь это, в сущности, кардинальный вопрос в нашей истории, и ответ на него должна дать история русской колонизации»,- заключает он [5, с. 12]. Причин тогда было несколько: малоземелье, ссылка, оборона. С несколькими издержками это продолжается до сих пор. Сюда надо отнести и урбанизационные процессы, так, раньше строили остроги и форты, теперь распространяют активное жилищное строительство в пригородных зонах, что приводит к еще большему обезлюживанию восточных в пользу западных территорий европейской части страны, но и это сойдет на нет, так как у крупных городов практически исчерпан ресурс укрупнения.

Есть опасность застрять в индустриальной составляющей прошлого века, ибо по «закону» Ципфа, который отлично применим к Западу, а у нас не работает в должной мере, для преимущественного развития необходимо, чтобы соот- ношение численности городов-миллионников располагались в определенной последовательности, кратной двум. «В России лишь Москва (12 млн.) и Санкт-Петербург (6 млн.) соответствуют этим требованиям, третий же город - Новосибирск (1.5 млн.) не дотягивает где-то три миллиона - их негде привлечь. «Решение государства о приоритетном развитии жилищного фонда крупных городов-миллионников не только ускоряет процесс деградации 1100 малых и средних городов, но и трансформирует весь уклад жизни россиян» - пишет А. Косоруков в статье «В скором времени многоэтажные «человейники» могут захлестнуть всю Россию. Чем это может грозить?» [6].

Общеизвестно, что вопросы пространственного развития должны носить комплексный характер, и не могут быть сведены только к проблемам ускорения экономического роста. «По сути дела, потенциал экономического роста в рамках сложившейся системы расселения на сегодняшний день исчерпан. Ускорение роста возможно только за счет новых технологий, то есть экзогенного фактора. Эндогенные факторы, со стороны пространственного развития, будут при этом не задействованы» [7]. Такому положению дел поспособствовал приоритет отраслевого планирования над территориальным в СССР.

Укрупнять города необходимо, так как урбанизация стимулирует экономическую деятельность и производительность труда, сокращает бедность, но подходить к этому процессу необходимо помощью индикативного планирования. В «Докладе о мировых городах» комиссии ООН-Хабитат прямо на это указывается: «Город, который планирует не только проецировать будущее из прошлых тенденций, он также объединяет государственный, частный и третий секторы вместе с общинами, чтобы построить коллективно предпочтительное будущее. Первенство здесь можно отдать коммуникативному процессу, где цели отражают чаяния населения, выраженные через пропаганду и массовое участие; большее внимание уделяется национальному и культурному контексту; и мероприятия по планированию лучше интегрированы в пространственные и отраслевые подразделения. планирование стало более многогранным, чем сосредоточенным исключительно на физическом дизайне мест, более восходящим, чем нисходящим, и более чутким к справедливости и окружающей среде» [8]. 
Трудно возразить, но в России, между тем, наступает кризис в развитии малых городов, сел и деревень, что катастрофически нарушает расселенческую ткань огромной страны. «Трудно представить поступательное движение нашей страны в лучшее будущее, если весь креативный класс соберется в нескольких мегаполисах, а сельские труженики - в нескольких районах черноземной полосы?»,- справедливо утверждает В.Л. Глазычев [9].

Этот процесс должен быть осмыслен должным образом. Первым опытом институциональной трансформации в России можно считать опыт, изложенный в книге «Вятское Земство среди других земств», составленной П.Голубевым для Парижской выставки и напечатанной на французском языке [10].

Авторы доклада «Стратегии территориального развития России», подготовленного комиссией регионального развития Общественной палаты РФ, отмечают: «Целостный мониторинг этих процессов в масштабе страны (да и в масштабе регионов) не ведется, и карты изменений обитаемого пространства не существует» [11]. 28 августа в Общественной палате состоялся круглый стол, на котором обсудили проект Стратегии пространственного развития России до 2025 года, представленный Минэкономразвития. Как рассказал врио директора департамента планирования территориального развития Минэкономразвития РФ Алексей Елин, при создании стратегии авторы столкнулись с тем, что последние 20-25 лет отсутствовали системные исследования по пространственному развитию, пробелы в статистике не позволяют выработать схему принятия решений. Как деревня и малые города выживают в таких условиях объяснил в статье «Почему до сих пор не умер русский народ» Теодор Шанин, в которой он ставит вопрос: как могло получиться, что почти в невыносимых условиях не наступило голода, народ удивительным образом выжил? Шанин дает объяснение, вводя понятие эксполярных (неформальных) экономических структур, которые и позволили россиянам выжить, несмотря на ужасы кризиса 1990-х. «Эксполярные структуры существуют в России столько же, сколько государство, и дольше, чем рыночный капитализм. Массовые индустриализация и урбанизация не заставили их исчезнуть (имеется в виду семейное выживание - А.С.), а только придали им иные формы»,заключает он [12].
Решения проблемы есть и об это пишет российский исследователь и практик Г.Тюрин: «В США в это время запустили программу развития территорий «War on poverty». С 1970-х годов community development превращается в один из ключевых приоритетов внутренней политики США. Результат: сегодня почти $60 \%$ рабочих мест в США создают небольшие производства. Именно локальное развитие стало отправной точкой в создании экономического чуда Южной Кореи (в виде так называемого «Движения за новую деревню», по-корейски - Сэмаыль ундон). Упор на локальную экономику позволил совершить огромный рывок в развитии Китая и Индии. Более 50\% экспорта Индии - это расположенные в глуши крестьянские кооперативы, небольшие промышленные цеха, которые здесь именуют SSI (small scale industries - мало-масштабные производства). Феноменален опыт местного развития скандинавских стран. Экономика многих провинций Финляндии - это сотни (или даже тысячи) маленьких фирм в разных отраслях, возникших в большинстве своем за последние десятилетия. Это такой большой умный муравейник из большого количества высокотехнологичных небольших производств» [13].

Зеркальное отражение Финляндии - это Карелия. Обладая схожими территориями разнятся по сути. В чем проблема? Потеря самоидентификации. Были и есть в разных странах - общины, землячества, земства, земли, где люди находят эффективность для развития территорий с ограниченной ресурсной базой. В этом суть. И Г.Тюрин находит выход с своих практических действиях, которые можно отследить на Алтае, в Коми, Архангельской области и т.Д.

Еще К.Маркс в письме к В.Засулич писал: Анализ, представленный в «Капитале», не дает, следовательно, доводов ни за, ни против жизнеспособности русской общины. Но специальные изыскания, которые я произвел на основании материалов, почерпнутых мной из первоисточников, убедили меня, что эта община является точкой опоры социального возрождения России, однако для того чтобы она могла функционировать как таковая, нужно было бы прежде всего устранить тлетворные влияния, которым она подвергается со всех сторон, а затем обеспечить ей нормальные условия свободного развития. Необходимо обратить на этот феномен пристальное внимание» [14]. 
Пока в России идет процесс самоидентификации территорий, на Западе уже создается так называемая экономика саморазрушения (китайский эксперимент), в которой производство новых благ замещает устаревшие и стимулирует рост производительности труда путем создания принципиально новых производств. «Трудно сейчас сказать, сохранит Китай свои лидирующие позиции в построении экономики нового типа или нет. Однако главный итог его социального эксперимента состоит в том, что он дал образец новой архитектуры национальной экономики. Судя по всему, в будущем нас ожидает волна копирования китайских социальных инноваций в разных странах и с разными аранжировками. При этом, скорее всего, этот вторичный опыт будет более успешным, чем в самом Китае» [15]. В подтверждение этому в «Известиях» появилась статья (авторы Е. Перцева и М.Перевощикова) под названием «Застройка на века: домам хотят прописать «срок годности». Это позволит покупателям понять, сколько они смогут жить до момента его сноса. Союз потребителей РФ обратился в Минстрой с инициативой создать для отрасли специальный ГОСТ по этому поводу» [16]. Главное начать, как говорил один из руководителей нашего государства. Потом пропишут ГОСТЫ на все. С той лишь разницей, что в Китае это делается от переизбытка ценностей подобного рода, а в России от недостатка. Сюда же примешивается и пространственный фактор. Исследователь А. Гачев заявляет, что «И вот у народа и государства в России разные темпоритмы во времени» (имеется ввиду внедрение сверху различных систем и идеологий, включая, как либеральные, так и коммунистические, не идущие из недр народного бытия - А.Н.). - итак несовпадение шага Пространства и такта Времени - вечная судьба и трагедия России, но и закономерность ее истории. Россия есть рассеянное бытие-небытие, разреженное пространство с островками жизни. Разрушим и построим» [17].

Президент РФ В.В.Путин обозначил в Указе о национальных целях развития России до 2030 года, подписанном 21 июля 2020 года в рамках национальной цели «Комфортная и безопасная среда для жизни»: улучшение жилищных условий не менее 5 миллионов семей ежегодно и увеличение объема жилищного строительства не менее чем до 120 миллионов квадратных метров в год.» [18]. Основной метраж видимо придется все же на городские поселения. Чем это может обернуться? Обращение к российской истории дает на это однозначный ответ. Власть страшно боялась пролетаризации крестьян, как самого многочисленного слоя населения, чего не скажешь о тогдашних либералах, впрочем, и те и другие ничего спрашивать у крестьян и не собирались, а зря, ибо аграрный вопрос, и тогда и сейчас, являлся вопросом сохранения нации как таковой. О чем совершенно справедливо указывает современный российский философ и публицист Бестужев-Лада в газете MK: «В конце прошлого века профессор Антонов из МГУ сделал величайшее открытие в области демографии. Его можно сформулировать следующим образом: «При переезде из деревни в город человек теряет потребность в семье и детях. И обрекает себя на вымирание». Не здесь ли кроется исконное противостояние интуитивно чувствующих беду славянофилов и окутанных туманом либеральных идей западников? [19] Жизнь это доказывает с неизбежностью, примером тому,- урбанизация России.

Поиски решения проблем территориального развития РФ в научной среде идут постоянно, некоторые разработки раскрывают суть проблемы и дают взвешенные решения, которые учитываются в государственных стратегиях, например, главной проблемой к структурной модернизации российской экономики следует признать то, что «Единое экономическое пространство, существовавшее в период СССР, распалось на отдельные территории и географические единицы (города), перспективы развития которых зависят в большей степени от их внутренних условий (во многом доставшихся им по наследству), чем от работы всей экономики в целом. Разные территории движутся автономно и разнонаправленно» [20].

Вывод напрашивается сам и заключается в том, что в РФ уже произошло самоуничтожение старых материальных ценностей. Необходимо переходить к новому производству на современных условиях труда. Как это сделать и чем руководствоваться? В Послании Президента Федеральному Собранию (от 1 марта 2018 года читаем): «Предлагаю развернуть масштабную программу пространственного развития России, включая развитие городов и других населённых пунктов, и как минимум удвоить расходы на эти цели в предстоящие шесть лет».

Думается, что велика роль науки в изменении политического и экономического поло- 
жения, пересмотре существующих стратегий развития и структур управления экономикой (оценка политической, экономической и социокультурной ситуации в России). В этом деле должны помочь разработки отечественных ученых разных лет, таких как М.Любавский, Г. Тю- рин, Л.Никифоров и т.д., а также и зарубежный опыт. Плодотворно на этой ниве трудятся неоэкономика, комиссия ООН, проводятся интересные эксперименты в КНР. Деньги обещаны. Цели определены. Проблемы очерчены.

\section{Библиографический список}

1. Никифоров Л. Смешанное общество (Российский вариант). - М.: Наука. 1999. - С. 125

2. Булгаков С. Н. Героизм и подвижничество / - «Public Domain», 1908. C.6

3. Немов А. Идея славянского возрождения.-М.: Типогр. Кушнерева. 1915.- С. 23-24

4. Гачев Г. Метальности народов мира.-М., ЭКСМО АЛГОРИТМ. 2008.-С. 115, 17

5. Любавский М.К. Историческая география России.- М.: Типогр Любимова. 1900.-С. 12

6. Косоруков А. В скором времени многоэтажные «человейники» могут захлестнуть всю Россию. Чем это может грозить? - M.: https://bankstoday.net/last-articles/v-skorom-vremeni-mnogoetazhnye-chelovejnikimogut-zahlestnut-vsyu-rossiyu-chem-eto-mozhet-grozit\#author-block

7. О стратегии пространственного развития. Анализ и предложения.- М.: Научно-исследовательский центр Олега Григорьева. 2019. http://neoconomica.ru/article.php?id=736

8. Программа Организации Объединенных Наций по населенным пунктам (ООН- Хабитат).- Веб-сайт: www. unhabitat.org

9. Глазычев В.Л. Глубинная Россия наших дней: стенограмма лекции профессора Вячеслава Глазычева, прочитанной в клубе Bilingua 16 сентября 2004 г. в рамках проекта «Публичные лекции Полит.py». URL: http:// polit.ru/article/2004/09/21/glaz.

10. Голубевъ П. Д. Земство России. краткий историко-статистический очерк культурной деятельности вятского земства в связи с деятельностью всех русских земств. Издание вятского губернского земства 1901 г.

11. Общественная палата Российской Федерации. Комиссия регионального развития. СТРАТЕГИИ ТЕРРИТОРИАЛЬНОГО РАЗВИТИЯ РОССИИ (к технологиям общественно-государственного партнерства).- М.: https://refdb.ru/look/1685865-pall.html. 2020.

12. Шанин Т. Почему до сих пор не умер русский народ // Эксперт.-2000. - No 1-2 (213).

13. Тюрин Г.В. / Как возродить российскую деревню: уроки и перспективы / - Москва: Московский Политех, 2016. - 176 c.

14. Маркс К., Энгельс Ф. Сочинения, Издание второе М.: Издательство политической литературы, 19551974 г.г.- Т. 19.- С. 163

15. Балацкий E.В. Китайская модель экономики будущего: развитие через перманентное саморазрушение// «Общество и экономика», № 8-9, 2011. С.292-305.

16. Перцева Е., Перевощикова M. Застройка на века: домам хотят прописать «срок годности».- Известия 21 июля 2020 https://iz.ru/1036450/evgeniia-pertceva-mariia-perevoshchikova/zastroika-na-veka-domam-khotiatpropisat-srok-godnosti

17. Гачев Г. Метальности народов мира.- М., ЭКСМО АЛГОРИТМ. 2008.- С. 115.

18. Послание Президента РФ Федеральному Собранию от 1 марта 2018 г. http://kremlin.ru/events/president/ news $/ 56957$.

19. Наумов А.С. Либеральный консерватизм в России: история и современность. Вестник Международного института менеджмента ЛИНК. 2014 (3):58-63.

20. О стратегии пространственного развития. Анализ и предложения. http://neoconomica.ru/article.php?id=736 